\title{
IndOLIZINE DERIVATIVES AS PHOSPHODIESTERASE IV INHIBITORS: DEVELOPMENT AND VALIDATION OF PHARMACOPHORE MODELS
}

\author{
Vikas Sharma ${ }^{1}$, Prabodh Chander Sharma ${ }^{1}$ and Vipin Kumar ${ }^{1,2 *}$ \\ ${ }^{1}$ Institute of Pharmaceutical Sciences, Kurukshetra University, Kurukshetra-136119, Haryana, India \\ ${ }^{2}$ Department of Pharmacy, School of Chemical Sciences and Pharmacy, Central University of Rajasthan, \\ Ajmer-305801, Rajasthan, India \\ ${ }^{*} E$-mail: vipkumar@curaj.ac.in \\ Tel.: +919416391274.
}

Received: Aug 12, 2016 / Revised: Aug 30, 2016 / Accepted: Aug 31, 2016

The challenges of drug discovery are largely overcome by computer aided designing and among various drug designing techniques, ligand based drug designing proves to be an effective one. Looking at the usefulness, in the present investigation ligand-based pharmacophore models has been developed by analyzing common chemical features of phosphodiesterase IV (PDE4) inhibitors. A dataset of 38 indolizine derivatives was selected in order to built pharmacophore models which were developed by using pharmacophoric features viz. hydrogen bond acceptor (A) and aromatic ring (R). In order to build up a statistically significant model, ARRRR.30 hypothesis was selected among different developed hypothesis with a $\mathbf{R}^{2}$ value $\mathbf{0 . 8 8 0}$. The selected hypothesis ARRRR.30 was further validated by performing external validation on a test set where $R^{2}$ was found to be 0.804 (between experimental and predicted activity). The developed model could be an efficient tool to develop new PDE4 inhibitors.

Key words: Indolizine; Phosphodiesterase IV inhibitors; QSAR; Rational Drug Design; Pharmacophore.

\section{INTRODUCTION}

Recognition of cyclic adenosine monophosphate (cAMP) as second messenger (Sutherland et al 1968), can be considered as an important discovery as cAMP mediates a wide range of cellular processes (Gloerich and Bos, 2010; Hofer and Lefkimmiatis, 2007) viz. inflammation (Moore and Willoughby, 1995), T-cell proliferation (Muñoz et al 1990), cardiac actions (Haikala et al 1997), CNS activity (Han et al 2006) etc. The control over cAMP is an important area where research is under progress in order to have potent drug against different ailments.

Phosphodiesterases (PDEs) regulates cAMP and cyclic guanosine monophosphate (cGMP) levels in cells and further catalyze their degradation into AMP and GMP, respectively (Chen et al 2011). Role of PDE4 isozyme in cAMP degradation which in turn mediates key inflammatory cytokines is widely recognized (Bäumer et al 2007; Oger et al 2005) and considering the fact that PDE4 inhibitors played an important role in ailments like inflammation, Alzheimer's disease, Parkinson's, asthma etc. (Castro et al 2005; Banner and Trevethick, 2004; Jeffery, 2005; O'Donnell and Zhang, 2004; Spina, 2004; Houslay et al 2005). Chen and coworkers (Chen et al 2011) designed and synthesized a series of novel indolizine-2-oxoacetamides as PDE4 inhibitors.

Different heterocyclic derivatives like pyrazole, quinoline, furan, indolizine etc. were designed in recent past as PDE4 inhibitors and availability of 
a 3D-QSAR model on PDE4 inhibitors will be an added advantage as it can screen different heterocyclic derivatives for their PDE4 inhibitory potential. However, some 3DPharmacophore models are available on PDE4 inhibitors like quinoline (Gaurav and Singh, 2014), benzodiazepine (Ducrot et al 2001) but to the best of our knowledge a 3D-model on indolizine derivative against PDE4 isozyme is not available. Considering the fact, we thought it is worthwhile to generate pharmacophore models on the indolizine derivatives against PDE4 inhibitor. A pharmacophore model with a decent $\mathrm{R}^{2}$ could be an effective way for designing of novel indolizine derivatives with potent PDE4 inhibitory potential.

In the present study, pharmacophoric features were aligned via PHASE module (Schrödinger) in order to develop 3D-QSAR models (PHASE, 2008). Generated hypothesis was then be used to find important structural features vital to judge PDE4 inhibitory potential of indolizine derivatives.

\section{EXPERIMENTAL}

\section{Dataset}

A dataset of 38 indolizine-2-oxoacetamides designed as PDE4 inhibitors (Chen et al 2011) was selected to develop a pharmacophore model. The chosen dataset was then randomly divided into training (17) and test set (21). The $\mathrm{IC}_{50}$ value of each derivative was converted into $\mathrm{pIC}_{50}$ (negative logarithm of $\mathrm{IC}_{50}$ ). The basic structures with their respective substituents are shown in Figure 1 and Table 1, respectively.<smiles>[R1]c1ccc(Cc2cc(C(=O)C(=O)Nc3ccc([R3])cc3)c3cc([R2])ccn23)cc1</smiles>

A<smiles>[R1]c1ccc(Cc2cc(C(=O)C(=O)Nc3c(Cl)cc([Y])cc3Cl)c3cc([R2])ccn23)cc1</smiles>

Fig. 1. Basic structures of selected indolizine derivatives

Table 1. PDE4 inhibitory activity data of indolizine derivatives

\begin{tabular}{|c|c|c|c|c|c|c|c|c|}
\hline $\begin{array}{l}\text { Ligand } \\
\text { No. }\end{array}$ & Series & $\mathbf{R}_{\mathbf{1}} ; \mathbf{R}_{2} ; \mathbf{R}_{\mathbf{3}}$ & $\mathbf{X}$ & $\begin{array}{c}\text { Exp. } \\
\text { Activity }\end{array}$ & $\begin{array}{c}\text { PLS } \\
\text { Factors }\end{array}$ & $\begin{array}{c}\text { Predicted } \\
\text { Activity }\end{array}$ & $\begin{array}{c}\text { Fitness } \\
\text { score }\end{array}$ & Dataset \\
\hline $1 \mathrm{a}$ & A & $\mathrm{H} ; \mathrm{H} ; \mathrm{H}$ & - & 6.458 & $1,2,3$ & $6.25 ; 6.38 ; 6.03$ & 2.19 & Test \\
\hline $1 \mathrm{~b}$ & A & $\mathrm{F} ; \mathrm{H} ; \mathrm{H}$ & - & 6.467 & $1,2,3$ & $5.75 ; 5.93 ; 6.25$ & 2.1 & Test \\
\hline 1c & A & $\mathrm{Cl} ; \mathrm{H} ; \mathrm{H}$ & - & 6.782 & $1,2,3$ & $5.72 ; 5.90 ; 6.25$ & 2.1 & Test \\
\hline 1d & A & $\mathrm{MeO} ; \mathrm{H} ; \mathrm{H}$ & - & 6.349 & $1,2,3$ & $6.85 ; 6.44 ; 6.35$ & 2.96 & Test \\
\hline $1 \mathrm{e}$ & A & $\mathrm{OH} ; \mathrm{H} ; \mathrm{H}$ & - & 6.485 & $1,2,3$ & $5.87 ; 6.07 ; 6.40$ & 2.1 & Test \\
\hline 1f & A & $\mathrm{NO}_{2} ; \mathrm{H} ; \mathrm{H}$ & - & 6.244 & $1,2,3$ & $5.83 ; 5.98 ; 6.22$ & 2.08 & Test \\
\hline $1 \mathrm{~g}$ & A & $\mathrm{NH}_{2} ; \mathrm{H} ; \mathrm{H}$ & - & 6.084 & $1,2,3$ & $6.40 ; 6.19 ; 6.42$ & 2.61 & Test \\
\hline $1 \mathrm{~h}$ & A & $\mathrm{CN} ; \mathrm{H} ; \mathrm{H}$ & - & 6.143 & $1,2,3$ & $6.58 ; 6.08 ; 5.87$ & 2.96 & Test \\
\hline $1 \mathrm{i}$ & A & $\mathrm{CF}_{3} ; \mathrm{H} ; \mathrm{H}$ & - & 6.429 & $1,2,3$ & $5.75 ; 5.92 ; 6.24$ & 2.06 & Test \\
\hline $\mathbf{1 j}$ & A & $i$-Pr; $\mathrm{H} ; \mathrm{H}$ & - & 6.441 & $1,2,3$ & $5.75 ; 5.92 ; 6.20$ & 2.09 & Test \\
\hline $1 \mathrm{k}$ & A & $\mathrm{F} ; \mathrm{OH} ; \mathrm{H}$ & - & 6.383 & $1,2,3$ & $6.69 ; 6.27 ; 6.18$ & 2.99 & Test \\
\hline $1 \mathrm{~L}$ & A & $\mathrm{F} ; \mathrm{Cl} ; \mathrm{H}$ & - & 6.621 & $1,2,3$ & $6.86 ; 6.49 ; 6.49$ & 3 & Test \\
\hline 1ad & $\mathrm{B}$ & $\mathrm{CN} ; \mathrm{Cl}$; NA & $\mathrm{N}$ & 7.086 & $1,2,3$ & $7.28 ; 7.77 ; 7.39$ & 2.15 & Test \\
\hline 1 ae & B & $\mathrm{F} ; \mathrm{Cl} ; \mathrm{NA}$ & $\mathrm{N}^{+}-\mathrm{O}^{-}$ & 7.267 & $1,2,3$ & $7.27 ; 7.72 ; 7.44$ & 2.18 & Test \\
\hline 1af & B & F; F; NA & $\mathrm{N}^{+} \mathrm{O}^{-}$ & 7.744 & $1,2,3$ & $6.78 ; 6.96 ; 7.66$ & 2.44 & Test \\
\hline $1 \mathrm{ag}$ & B & $\mathrm{Cl} ; \mathrm{H}$; NA & $\mathrm{N}^{+} \mathrm{O}^{-}$ & 7.721 & $1,2,3$ & $7.11 ; 7.50 ; 7.10$ & 2.16 & Test \\
\hline $1 \mathrm{ah}$ & B & $\mathrm{MeO} ; \mathrm{H} ; \mathrm{NA}$ & $\mathrm{N}^{+}-\mathrm{O}^{-}$ & 7.096 & $1,2,3$ & $6.82 ; 7.01 ; 7.70$ & 2.4 & Test \\
\hline 1ai & B & $\mathrm{OH} ; \mathrm{H} ; \mathrm{NA}$ & $\mathrm{N}_{-}^{+} \mathrm{O}^{-}$ & 7.537 & $1,2,3$ & $7.31 ; 7.75 ; 7.43$ & 2.17 & Test \\
\hline
\end{tabular}




\begin{tabular}{|c|c|c|c|c|c|c|c|c|}
\hline 1aj & $\mathrm{B}$ & $\mathrm{F} ; \mathrm{H} ; \mathrm{NA}$ & $\mathrm{CH}$ & 5 & $1,2,3$ & $4.94 ; 5.48 ; 5.72$ & 2.44 & Test \\
\hline 1ak & B & F; H; NA & $\mathrm{CCF}_{3}$ & 5 & $1,2,3$ & $4.48 ; 4.86 ; 5.10$ & 2.37 & Test \\
\hline $2 b$ & B & F; H; NA & $\mathrm{N}^{+} \mathrm{O}^{-}$ & 7.537 & $1,2,3$ & $6.73 ; 6.90 ; 7.58$ & 2.43 & Test \\
\hline $1 \mathrm{~m}$ & $\mathrm{~A}$ & $\mathrm{Cl} ; \mathrm{MeO} ; \mathrm{H}$ & - & 6 & $1,2,3$ & $6.18 ; 5.92 ; 6.11$ & 2.6 & Training \\
\hline $1 n$ & $\mathrm{~A}$ & $\mathrm{CN} ; \mathrm{H} ; 2-\mathrm{Cl}$ & - & 5.327 & $1,2,3$ & $5.57 ; 5.68 ; 5.97$ & 1.89 & Training \\
\hline 10 & $\mathrm{~A}$ & $\mathrm{Cl} ; \mathrm{H} ; 2,4-(\mathrm{Cl})_{2}$ & - & 7.075 & $1,2,3$ & $5.67 ; 5.97 ; 6.67$ & 1.99 & Training \\
\hline $1 p$ & $\mathrm{~A}$ & $\mathrm{CN} ; \mathrm{H} ; 2,4-(\mathrm{Cl})_{2}$ & - & 6.602 & $1,2,3$ & $6.90 ; 6.41 ; 6.26$ & 2.91 & Training \\
\hline $1 \mathrm{q}$ & $\mathrm{A}$ & $\mathrm{F} ; \mathrm{H} ; 2,4-(\mathrm{Br})_{2}$ & - & 5 & $1,2,3$ & $6.53 ; 5.96 ; 5.38$ & 2.75 & Training \\
\hline $1 \mathrm{r}$ & $\mathrm{A}$ & $\mathrm{CN} ; \mathrm{H} ; 2,4-(\mathrm{MeO})_{2}$ & - & 5 & $1,2,3$ & $6.02 ; 5.98 ; 4.85$ & 2.09 & Training \\
\hline $1 \mathrm{~s}$ & $\mathrm{~A}$ & $\mathrm{CN} ; \mathrm{H} ; 6-(\mathrm{OMe})$ & - & 5.823 & $1,2,3$ & $6.06 ; 5.63 ; 5.64$ & 2.58 & Training \\
\hline $1 \mathrm{t}$ & $\mathrm{B}$ & $\mathrm{CN} ; \mathrm{H} ; \mathrm{NA}$ & $\mathrm{N}$ & 6.935 & $1,2,3$ & $7.15 ; 7.57 ; 7.10$ & 2.14 & Training \\
\hline $1 \mathbf{u}$ & $\mathrm{B}$ & $\mathrm{F} ; \mathrm{H} ; \mathrm{NA}$ & $\mathrm{N}$ & 7.886 & $1,2,3$ & $6.93 ; 7.17 ; 7.91$ & 2.44 & Training \\
\hline $1 v$ & $\mathrm{~B}$ & $\mathrm{Cl} ; \mathrm{H}$; NA & $\mathrm{N}$ & 7.795 & $1,2,3$ & $7.77 ; 7.45 ; 7.64$ & 2.84 & Training \\
\hline $1 w$ & $\mathrm{~B}$ & $\mathrm{MeO} ; \mathrm{H} ; \mathrm{NA}$ & $\mathrm{N}$ & 7.397 & $1,2,3$ & $7.30 ; 7.79 ; 7.54$ & 2.17 & Training \\
\hline $1 \mathrm{x}$ & $\mathrm{B}$ & $\mathrm{OH} ; \mathrm{H} ; \mathrm{NA}$ & $\mathrm{N}$ & 7.823 & $1,2,3$ & $7.50 ; 8.03 ; 7.78$ & 2.17 & Training \\
\hline $1 y$ & $\mathrm{~B}$ & $\mathrm{Cl} ; \mathrm{Cl} ; \mathrm{NA}$ & $\mathrm{N}$ & 7.585 & $1,2,3$ & $6.08 ; 6.56 ; 7.59$ & 1.98 & Training \\
\hline $1 z$ & $\mathrm{~B}$ & $\mathrm{~F} ; \mathrm{Cl} ; \mathrm{NA}$ & $\mathrm{N}$ & 7.552 & $1,2,3$ & $7.47 ; 8.03 ; 7.85$ & 2.19 & Training \\
\hline 1 aa & $\mathrm{B}$ & F; F; NA & $\mathrm{N}$ & 7.886 & $1,2,3$ & $7.84 ; 7.55 ; 7.78$ & 2.85 & Training \\
\hline $1 \mathrm{ab}$ & $\mathrm{B}$ & $\mathrm{OH} ; \mathrm{Cl}$; $\mathrm{NA}$ & $\mathrm{N}$ & 8.698 & $1,2,3$ & $8.10 ; 7.88 ; 8.21$ & 2.85 & Training \\
\hline $1 \mathrm{ac}$ & $\mathrm{B}$ & $\mathrm{MeO} ; \mathrm{Cl} ; \mathrm{NA}$ & $\mathrm{N}$ & 7.92 & $1,2,3$ & $7.57 ; 8.14 ; 7.93$ & 2.13 & Training \\
\hline
\end{tabular}

\section{Pharmacophore modeling}

In initial stage, Maestro algorithm and LigPrep program (PHASE software) were used to draw high quality 3D-structures with perfect chirality which were then subjected to ionization at $\mathrm{pH} 7$. The conformers of the training set molecules were generated with Monte Carlo method by OPLS-2005 force field as provided in MacroModel 9.62008 and were subsequently minimized using Truncated Newton Conjugate Gradient (PHASE, 2008; Maestro, 2008).

During generation of hypothesis, two pharmacophoric features i.e. aromatic ring (R) and hydrogen bond acceptor (A) were appeared frequently. These pharmacophoric features were used to generate pharmacophore sites to map all essential chemical features of dataset molecules. Pharmacophoric sites (3-6) were fixed for all the chemical features and a common pharmacophore was generated which in turn leads to creation of various pharmacophore hypotheses by using PHASE, 2008. The regression was carried out on hypotheses with stepwise increasing number of PLS factors. Later on, by employing training set molecules (after setting a grid spacing of $1 \mathrm{~A}^{\circ}$ ) 3D-QSAR models were created. In the next step, the common pharmacophore hypotheses were assessed on the basis of their survival score in order to find finest configuration of the active molecules using root mean square deviation value of $1.2 \mathrm{~A}^{\circ}$. The scoring of hypotheses were performed using default parameters.

The stepwise process of QSAR model development is presented in Figure 2 while detailed methodology has already been explained (Kaushik et al 2012; Kaur et al 2012; Bansal et al 2011; Rani and Kumar, 2011).

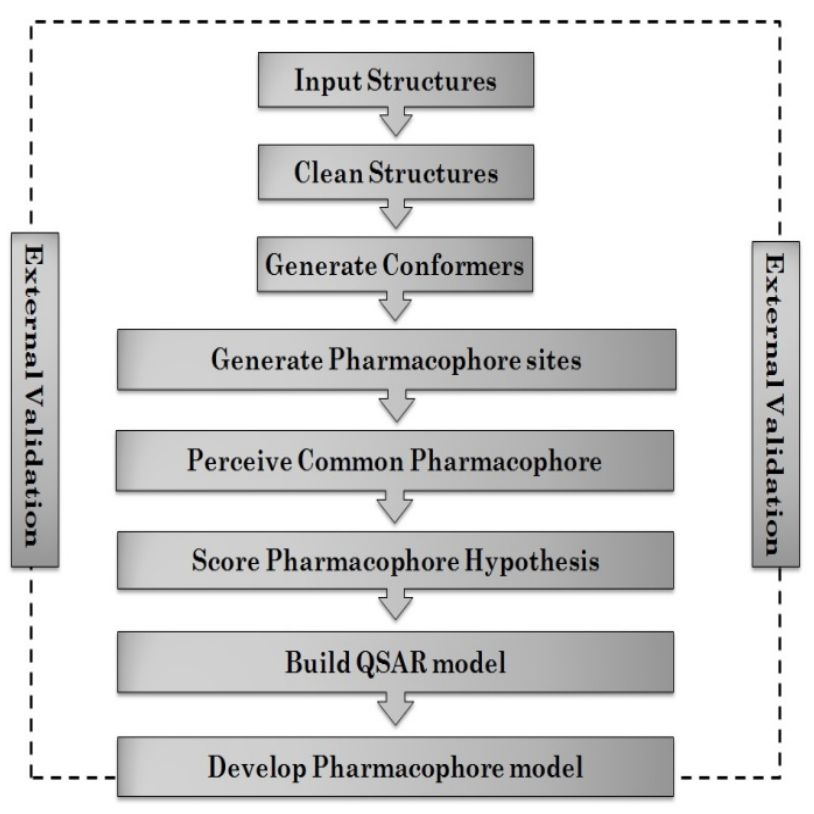

Fig. 2. Phase workflows 


\section{Validation of pharmacophore model}

For the appraisal of the best hypotheses, validation used to be carried out to verify the strong correlation between the structures and their corresponding biological activity. In brief, both test and training set molecules were processed using similar protocol followed by activity prediction of test molecules employing the pharmacophore model developed in the study. Finally, determination of a prospective correlation between experimental and predicted activities of the test molecules was envisaged.

\section{RESULTS AND DISCUSSION}

In our recent review, anti-tubercular, antiproliferative, antimicrobial, anti-inflammatory potential of different indolizine derivatives was discussed (Sharma and Kumar, 2014). Furthermore, computational techniques like docking, molecular modeling play an important role in drug discovery (Kumar, 2011; Sharma et al 2011; Bansal et al 2011; Balasubramanian and Vijaya Gopal, 2012). Ligand-based drug design is such a significant technique by which a QSAR model may be developed that can portray vital structural requirements required for a particular biological activity.

The present study envisages the development of pharmacophore model by using 38 molecules in which aromatic rings (R) and hydrogen bond acceptor (A) were engaged as pharmacophoric features for creation of interaction sites. Different pharmacophore hypotheses (five features) were developed and each of them was further evaluated via stringent scoring function analysis. Table 2 portrays the results of different pharmacophore hypotheses.
ARRRR.30 represented the best hypothesis (Figure 3) with highest $\mathrm{R}^{2}$ value of 0.880 and good survival score of 3.396, featuring a hydrogen bond acceptor (A) and aromatic rings (R). However the specifications of ARRRR.30 model are presented in Table 3 (distances) and Table 4 (angles).

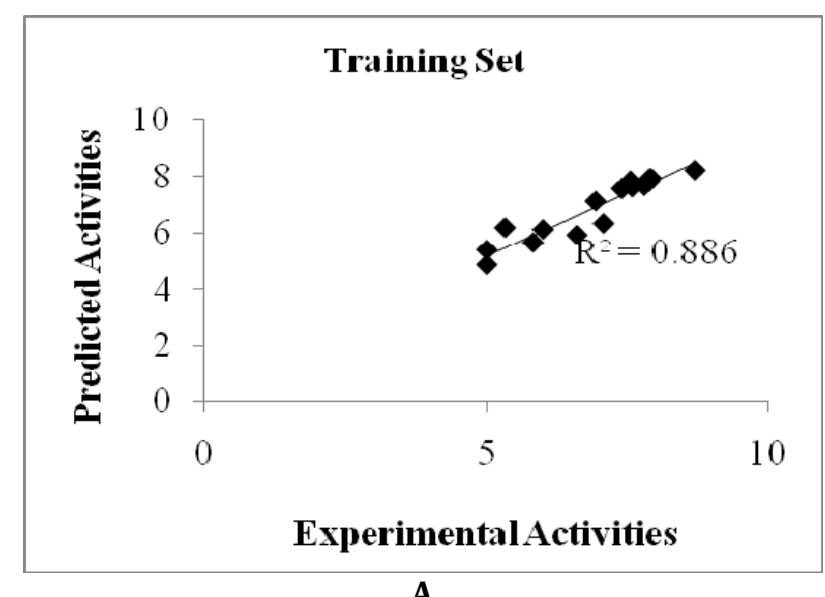

A

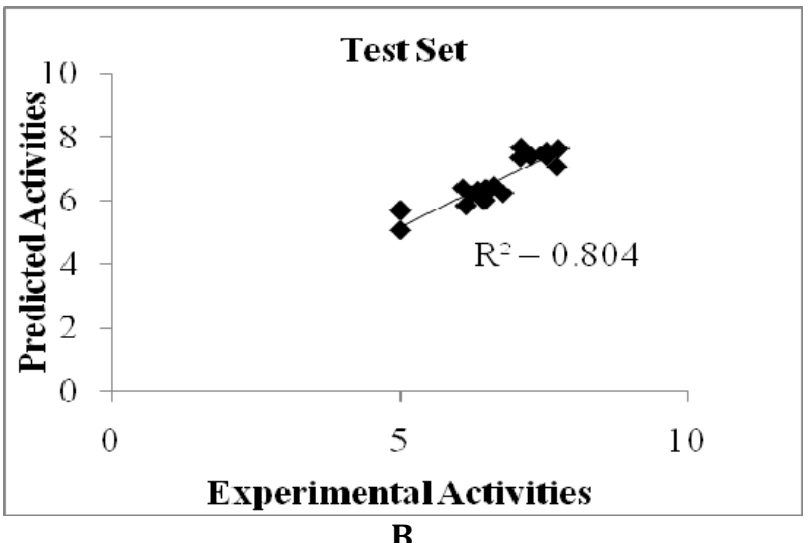

Fig. 3. Relationship between experimental and predicted PDE4 inhibitory activity of training set (A) molecules and test set (B) molecules

Table 2. Parameters of five featured pharmacophore hypothesis

\begin{tabular}{|c|c|c|c|}
\hline Hypothesis & Survival & R-squared & F \\
\hline ARRRR.21 & 3.523 & $0.637 ; 0.803 ; 0.862$ & $61.5 ; 69.4 ; 69$ \\
\hline ARRRR.22 & 3.481 & $0.609 ; 0.732 ; 0.872$ & $54.5 ; 46.4 ; 75.1$ \\
\hline ARRRR.30 & $\mathbf{3 . 3 9 6}$ & $\mathbf{0 . 6 0 0 ; 0 . 7 2 7 ; 0 . 8 8 0}$ & $\mathbf{5 2 . 7} ; \mathbf{4 5 . 3 ; 8 1}$ \\
\hline AARRR.31 & 3.087 & $0.438 ; 0.646 ; 0.860$ & $27.4 ; 31.1 ; 68$ \\
\hline ARRRR.29 & 2.835 & $0.645 ; 0.736 ; 0.849$ & $63.7 ; 47.4 ; 61.9$ \\
\hline AARRR.2 & 2.417 & $0.448 ; 0.692 ; 0.821$ & $28.4 ; 38.2 ; 50.5$ \\
\hline
\end{tabular}

Fitness score of a QSAR model could be useful in judging the correctness of a model as it was calculated by superimposing each ligand on the best available model i.e. ARRRR.30 in this study (Table 2). The superimposition measures the distance between the selected pharmacophoric features and the centre of the hypothesis feature which further evaluates its mapping potential. In order to validate the developed model, activity prediction of training set was performed besides survival score analysis. Therefore, the ARRRR.30 model was regressed against the training set. The PDE4 inhibitory activity data related to predicted and experimental activities of training 
Table 3. Distances between different sites of 'model ARRRR.30'

\begin{tabular}{|c|c|c|c|}
\hline Entry & Site1 & Site2 & Distance \\
\hline ARRRR.30 & A3 & R7 & 3.48 \\
\hline ARRRR.30 & A3 & R9 & 4.136 \\
\hline ARRRR.30 & A3 & R8 & 5.558 \\
\hline ARRRR.30 & A3 & R10 & 7.437 \\
\hline ARRRR.30 & R7 & R9 & 2.153 \\
\hline ARRRR.30 & R7 & R8 & 7.239 \\
\hline ARRRR.30 & R7 & R10 & 4.744 \\
\hline ARRRR.30 & R9 & R8 & 8.907 \\
\hline ARRRR.30 & R9 & R10 & 6.533 \\
\hline ARRRR.30 & R8 & R10 & 8.23 \\
\hline
\end{tabular}

Table 4. Angles between different sites of 'model ARRRR.30'

\begin{tabular}{|c|c|c|c|c|}
\hline Entry & Site1 & Site2 & Site3 & Angle \\
\hline ARRRR.30 & R7 & A3 & R9 & 31.4 \\
\hline ARRRR.30 & R7 & A3 & R8 & 104 \\
\hline ARRRR.30 & R7 & A3 & R10 & 29.8 \\
\hline ARRRR.30 & R9 & A3 & R8 & 133 \\
\hline ARRRR.30 & R9 & A3 & R10 & 61.1 \\
\hline ARRRR.30 & R8 & A3 & R10 & 77.1 \\
\hline ARRRR.30 & A3 & R7 & R9 & 91.4 \\
\hline ARRRR.30 & A3 & R7 & R8 & 48.2 \\
\hline ARRRR.30 & A3 & R7 & R10 & 128.8 \\
\hline ARRRR.30 & R9 & R7 & R8 & 135.7 \\
\hline ARRRR.30 & R9 & R7 & R10 & 139.5 \\
\hline ARRRR.30 & R8 & R7 & R10 & 84 \\
\hline ARRRR.30 & A3 & R9 & R7 & 57.3 \\
\hline ARRRR.30 & A3 & R9 & R8 & 27.2 \\
\hline ARRRR.30 & A3 & R9 & R10 & 85.3 \\
\hline ARRRR.30 & R7 & R9 & R8 & 34.6 \\
\hline ARRRR.30 & R7 & R9 & R10 & 28.2 \\
\hline ARRRR.30 & R8 & R9 & R10 & 62.2 \\
\hline ARRRR.30 & A3 & R8 & R7 & 27.8 \\
\hline ARRRR.30 & A3 & R8 & R9 & 19.9 \\
\hline ARRRR.30 & A3 & R8 & R10 & 61.7 \\
\hline ARRRR.30 & R7 & R8 & R9 & 9.7 \\
\hline ARRRR.30 & R7 & R8 & R10 & 35 \\
\hline ARRRR.30 & R9 & R8 & R10 & 44.6 \\
\hline ARRRR.30 & A3 & R10 & R7 & 21.4 \\
\hline ARRRR.30 & A3 & R10 & R9 & 33.7 \\
\hline ARRRR.30 & A3 & R10 & R8 & 41.2 \\
\hline ARRRR.30 & R7 & R10 & R9 & 12.4 \\
\hline ARRRR.30 & R7 & R10 & R8 & 61 \\
\hline ARRRR.30 & R9 & R10 & R8 & 73.2 \\
\hline
\end{tabular}

set molecules derived from ARRRR.30 hypothesis is presented in Table 1. Figure 4 illustrates a good correlation of 0.886 between predicted and experimental PDE4 inhibitory activity of training set molecules using ARRRR.30 model. In the next step, predictive character or in other words validation of developed model was performed by assessing the PDE4 inhibitory activity of test molecules by using ARRRR.30 model which will in turn compared to experimental data.

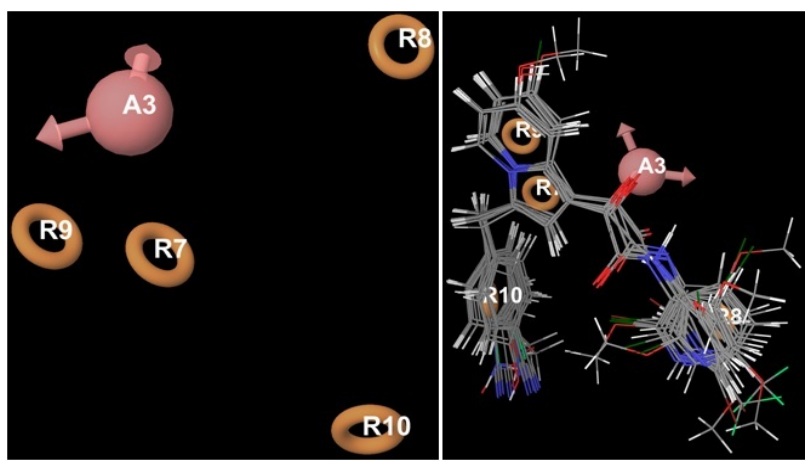

Fig. 4. (A) PHASE generated pharmacophore model ARRRR.30 illustrating one hydrogen bond acceptor (A3; pink), and four aromatic rings (R7; R8; R9; R10 orange) features. (B) All ligands overlapped on the generated model ARRRR.30.

In accordance with the observation of Goyal and co-workers, the squared predictive correlation coefficient of ARRRR.30 model is more than 0.60 (Goyal and Kumar, 2011), so ARRRR.30 model could be useful model in order to assess PDE4 inhibitory activity of indolizine derivatives. A correlation value of 0.804 was found between test and training set molecules (Figure 3).

\section{CONCLUSION}

In this paper, different pharmacophore models were generated by incorporating indolizine derivatives with PDE4 inhibitory activity. Among the developed models, hypothesis ARRRR.30 was selected on the basis of good regression coefficient value of 0.880 and survival score 3.396. The selected model constitutes one hydrogen bond acceptor (A) and four aromatic rings (R). ARRRR.30 model exhibits a correlation value of 0.886 in case of training set while on the other hand, ARRRR.30 model was effectively validated by assessing the activity of test molecules $\left(\mathrm{R}^{2}=0.804\right)$. Considering the correlation values and validation data it would be appropriate to mention ARRRR.30 as a good QSAR model which could be a valuable tool for designing of new PDE4 inhibitors.

\section{ACKNOWLEDGEMENTS}

Authors are thankful to Schrodinger LLC., Portland, USA for providing software for research purpose. Mr. Vikas Sharma is thankful to All India Council for Technical Education, India for providing National Doctoral Fellowship for PhD research work vide letter no. F.No.14/ AICTE/RIFD/NDF(Policy-I)/02/2012-13. 


\section{REFERENCES}

Balasubramanian R, Vijaya Gopal R. Design and in silico analysis of ring-A monosubstituted chalcones as potential anti-inflammatory agents. Bull. Pharm. Res. 2012;2(2):70-7.

Banner KH, Trevethick MA. PDE4 inhibition: a novel approach for the treatment of inflammatory bowel disease. Trends Pharmacol. Sci. 2004;25(8):430-6. [DOI: 10.1016/j.tips.2004.06.008]

Bansal H, Sharma A, Sharma V, Kumar V. Pharmacophore modeling studies on xanthones as monoamine oxidase-A inhibitors. Bull. Pharm. Res. 2011;1(1):15-21.

Bäumer W, Hoppmann J, Rundfeldt C, Kietzmann M. Highly selective phosphodiesterase 4 inhibitors for the treatment of allergic skin diseases and psoriasis. Inflamm. Allergy Drug Targets 2007;6(1):17-26. [DOI: 10.2174/187152807780077318]

Castro A, Jerez MJ, Gil C, Martinez A. Cyclic nucleotide phosphodiesterases and their role in immunomodulatory responses: advances in the development of specific phosphodiesterase inhibitors. Med. Res. Rev. 2005;25(2): 229-44. [DOI: 10.1002/med.20020]

Chen S, Xia Z, Nagai M, Lu R, Kostik E, Przewloka T, Song M, Chimmanamada D, James D, Zhang S, Jiang J, Ono M, Koya $\mathrm{K}$, Sun L. Novel indolizine compounds as potent inhibitors of phosphodiesterase IV (PDE4): structure-activity relationship. Med. Chem. Commun. 2011;2(3):176-80. [DOI: 10.1039/C0MD00215A]

Ducrot P, Andrianjara CR, Wrigglesworth R. CoMFA and CoMSIA 3D-quantitative structure-activity relationship model on benzodiazepine derivatives, inhibitors of phosphodiesterase IV. J. Comput. Aided Mol. Des. 2001; 15(9):767-85. [DOI: 10.1023/A:1013104713913]

Gaurav A, Singh R. Pharmacophore modeling, 3DQSAR, and docking-based design of polysubstituted quinolines derivatives as inhibitors of phosphodiesterase 4, and preliminary evaluation of their anti-asthmatic potential. Med. Chem. Res. 2014;23(12):5008-30. [DOI: 10.1007/s0 0044-014-1048-3]

Gloerich M, Bos JL. Epac: defining a new mechanism for cAMP action. Annu. Rev. Pharmacol. Toxicol. 2010;50:35575. [DOI: 10.1146/annurev.pharmtox.010909.105714]

Goyal I, Kumar V. Pharmacophore modeling studies on aryl thioxothiazolidinones as ADAMTS-5 (Aggrecanase-2) inhibitors. Der Pharma Chem. 2011;3(2):448-59.

Haikala H, Kaheinen P, Levijoki J, Lindén IB. The role of cAMP- and cGMP-dependent protein kinases in the cardiac actions of the new calcium sensitizer, levosimendan. Cardiovasc. Res. 1997;34(3):536-46. [DOI: 10.1016/S0008-6363(97)00057-6]

Han MH, Bolanos CA, Green TA, Olson VG, Neve RL, Liu RJ, Aghajanian GK, Nestler EJ. Role of cAMP response element-binding protein in the rat locus ceruleus: regulation of neuronal activity and opiate withdrawal behaviors. J. Neurosci. 2006;26(17):4624-9. [DOI: 10.152 3/JNEUROSCI.4701-05.2006]

Hofer AM, Lefkimmiatis K. Extracellular calcium and cAMP: second messengers as "third messengers"? Physiology 2007;22:320-7. [DOI: 10.1152/physiol.00019.2007]

Houslay MD, Schafer P, Zhang KY. Keynote review: phosphodiesterase-4 as a therapeutic target. Drug Discov.
Today 2005;10(22):1503-19. [DOI: 10.1016/S1359-6446 (05)03622-6]

Jeffery P. Phosphodiesterase 4-selective inhibition: novel therapy for the inflammation of COPD. Pulm. Pharmacol. Ther. 2005;18(1):9-17. [DOI: 10.1016/j.pupt. 2004.09.02 7]

Kaur P, Sharma V, Kumar V. Pharmacophore modelling and 3D-QSAR studies on $\mathrm{N}^{3}$-phenylpyrazinones as corticotrophin-releasing factor-1 (CRF1) receptor antagonists. Int. J. Med. Chem. 2012;(2012):1-13. (Article ID 452325) [DOI: 10.1155/2012/452325]

Kaushik U, Sharma V, Kumar V. Computation of pharmacophore models for the prediction of mitogenactivated protein kinase activated protein kinase- 2 inhibitory activity of pyrrolopyridines. Med. Chem. Res. 2012;21(11):3777-84. [DOI: 10.1007/s00044-011-99 10-z]

Kumar V. Topological models for the prediction of tyrosine kinase inhibitory activity of 4-anilinoquinazolines. Bull. Pharm. Res. 2011;1(2):53-60.

Maestro, Version 8.5, Schrodinger, LLC, NY2008.

Moore AR, Willoughby DA. The role of cAMP regulation in controlling inflammation. Clin. Exp. Immunol. 1995;101 (3):387-9. [DOI: 10.1111/j.1365-2249.1995.tb0 3123.x]

Muñoz E, Zubiaga AM, Merrow M, Sauter NP, Huber BT. Cholera toxin discriminates between $\mathrm{T}$ helper 1 and 2 cells in T cell receptor-mediated activation: role of cAMP in T cell proliferation. J. Exp. Med. 1990;172(1):95-103. [DOI: 10.1084/jem.172.1.95]

O'Donnell JM, Zhang HT. Antidepressant effects of inhibitors of cAMP phosphodiesterase (PDE4). Trends Pharmacol. Sci. 2004;25:158-63. [DOI: 10.1016/j.tips.2004.01.003]

Oger S, Mehats C, Dallot E, Cabrol D, Leroy MJ. Evidence for a role of phosphodiesterase 4 in lipopolysaccharidestimulated prostaglandin E2 production and matrix metalloproteinase-9 activity in human amniochorionic membranes. J. Immunol. 2005;174(12):8082-9. [DOI: 10.4 049/jimmunol.174.12.8082]

PHASE, Version 3.0, Schrodinger, LLC, NY2008.

Rani P, Kumar V. Development of pharmacophore models for predicting HIV-1 reverse transcriptase inhibitory activity of pyridinone derivatives. Pharm. Chem. J. 2011; 45(1):36-42. [DOI: 10.1007/s11094-011-0556-4]

Sharma V, Wakode SR, Lather V, Mathur R, Fernandes MX. Structure based rational drug design of selective phosphodiesterase-4 ligands as anti-inflammatory molecules. Bull. Pharm. Res. 2011;1(2):33-40.

Sharma V, Kumar V. Efficient way of drug designing: a comprehensive review on computational techniques. Bull. Pharm. Res. 2014;4(3):118-23.

Sharma V, Kumar V. Indolizine: a biologically active moiety. Med. Chem. Res. 2014;23(8):3593-606. [DOI: 10.1007/s0 0044-014-0940-1]

Spina D. The potential of PDE4 inhibitors in respiratory disease. Curr. Drug Targets Inflamm. Allergy 2004;3(3): 231-6. [DOI: 10.2174/1568010043343822]

Sutherland EW, Robison GA, Butcher RW. Some aspects of the biological role of adenosine 3', 5'-monophosphate (cyclic AMP). Circulation 1968;37(2):279-306. [DOI: 10.11 61/01.CIR.37.2.279] 